\title{
Nutritional Status of Mothers and Its Determinants in Alemtidad Area, Khartoum
}

\author{
Waled Amen Mohammed Ahmed ${ }^{*}$, Eiman Abdalla Ahmed ${ }^{2}$, Khalid Ahmad Omar Arafa ${ }^{3}$, \\ Ehab Ibrahim Salih El-Amin ${ }^{4}$, Ziad M. Alostaz1, Khalid Eltahir Khalid5 \\ ${ }^{1}$ Nursing Department, Faculty of Applied Medical Sciences, Albaha University, Al Bahah, Saudi Arabia \\ ${ }^{2}$ Altaiseer Medical Complex, Khartoum, Sudan \\ ${ }^{3}$ Faculty of Applied Medical Sciences, Albaha University, Al Bahah, Saudi Arabia \\ ${ }^{4}$ Basic Sciences Department, Faculty of Applied Medical Sciences, Albaha University, Al Bahah, Saudi Arabia \\ ${ }^{5}$ Faculty of Applied Medical Sciences, Albaha University, Al Bahah, Saudi Arabia \\ Email: weliameen1980@yahoo.com
}

Received 10 October 2014; revised 8 November 2014; accepted 16 November 2014

Copyright (C) 2014 by authors and Scientific Research Publishing Inc.

This work is licensed under the Creative Commons Attribution International License (CC BY). http://creativecommons.org/licenses/by/4.0/

(c) (i) Open Access

\section{Abstract}

Background: Nutritional status of mothers is considered one of the major problems facing mothers in the world. The nutrition plays a major role in mothers and child health. Objective: This study aims to assess mothers' nutritional status and its determinants in Alemtidad area, Khartoum. Methods: A descriptive community based survey was conducted in the Alemtidad area of Khartoum between November 2012 and December 2012. One hundred and eighty mothers were selected by simple randomization. Data were collected by using structured designed questionnaire which was then analyzed by (SPSS) program version 20. Results: The study conducted among mothers in Alemtidad area; their age ranged between 19 and 86 years with the mean age $38 \pm 12$ years. From those mothers about half were unemployed, and having mainly primary and secondary educational level. 81.1\% of mothers were not able to select the proper food according to age and nutrients and about $71.1 \%$ of mothers took two meals per day and $23.3 \%$ one meals per day, and only 5.6 take three meals per day. The Body Mass Index (BMI) was calculated to measure the nutrition status of mothers; this study shows that mothers in Alemtidad are mainly overweight and obese, 45.6\% and $18 \%$ respectively and only $35 \%$ within normal range of Body Mass Index (BMI). Conclusion: The study concludes that mothers are either overweight or obese $(45.6 \%, 17.7 \%$ respectively). Compared to national and international statistics the findings of this study reflect high Body Mass Index (BMI) of mothers in Alemtidad.

*Corresponding author.

How to cite this paper: Ahmed, W.A.M., Ahmed, E.A., Arafa, K.A.O., El-Amin, E.I.S., Alostaz, Z.M. and Khalid, K.E. (2014) Nutritional Status of Mothers and Its Determinants in Alemtidad Area, Khartoum. Food and Nutrition Sciences, 5, 22032208. http://dx.doi.org/10.4236/fns.2014.522233 


\section{Keywords}

\section{Nutritional Status, Determinant of Nutritional Status, Food Consumption, Mothers}

\section{Introduction}

The nutritional and health status of mothers is of great concern in the contemporary world. Because the multiple roles played by mothers (bearing, lactating, serving, and feeding others) give rise to serious health and nutritional problems. The situation is even worse in countries where societal norms and sex discrimination have forcefully subjected mothers to satisfy the health and nutritional needs of their families at their own expense [1]. Mothers are, thus, vulnerable to malnutrition for social and biological reasons [2].

Nutrition needs typically increase more for mothers during any other stage in a woman's adult life. However, because differing role nutrients play in tissue development and growth as well as nutrient, specific change in mothers' homeostasis during their life and nutrients requirement do not increase uniformly [3]. For mothers of childbearing age, good nutrition is important for increasing demands at this period [4].

Maternal non-modifiable, non-biological factors that affect mental and physical well-being have been associated with mothers' nutrition [5] [6]. Although it is increasingly acknowledged that social factors (food preparation, cooking, ceremonies and types of food items used, etc.) play a significant role in micronutrient status and health of mothers [5] [6], studies on impacts of nutritional status on pregnancy outcomes have produced conflicting results [7]. A study in Germany found that, mothers with lowest level of education had a significantlyelevated risk of small-for-gestational age newborns compared to mothers with highest level of education, with the distribution of factors known to influence intrauterine growth varying with educational level. It was also reported that the risk of preterm birth has been reported in mothers of low socioeconomic status [8].

This study, therefore, aims at assessing nutritional status of mothers and identifying the underlying determinants affecting their nutrition in Alemtidad area, Khartoum. The information gathered is expected to help plan and implement a comprehensive package for improving their health and nutritional status.

\section{Methods}

A descriptive, community based study was conducted in Alemtidad area which located in the center of Khartoum city surrounded by Almahaly market from the south, Aldeim area from the north, Alshaapy market from the west and Mohamed Najeeb Street from the east. The study has been conducted in a period from September 2012 to January 2013.

The independent variable of this study was educational level, occupation, age, and meals habits and the dependent variable was the nutritional status of mothers.

Study population consists of mothers and their under-five children in Alemtidad. This study targeted all mothers who are living in Alemtidad area at the time of study; they are 4200 mothers, the sample size selected randomly by simple random sample after consent. The calculated sample size was 180 mothers using WHO required sample size table.

Patients' confidentiality and privacy are guaranteed; also the information obtained is remained strictly confidential. This has been achieved through the safe keeping of the completed forms, and the entry of personal data on computers only as a code with no space for name, address or other identifying variables.

The data has been collected by house to house visit using self-designed structured questionnaire, and then the collected data has been cleaned at the data collection field, organized into a master sheet, and then entered into the computer software, and analyzed using the software Statistical Package for Social Science (SPSS) version 20. Both dependent and independent variables have been displayed as frequency tables, charts and graphs; then Chisquare test to test the relationships between categorical variables, where only values equal to or less than 0.05 are considered as significant.

\section{Results}

The study was conducted among 180 mothers in Alemtidad at Khartoum State. The participants' demographic 
characteristics were described. The mean age of participants was 39.85 (40 \pm 5 years) and $55.6 \%$ of participants were unemployed, most of them (95.6\%) had primary or secondary education or above. The economic status (family income per family members) of surveyed participants was low (only $28.9 \%$ have good economic status) as seen in (Table 1$)$.

The Body Mass Index was calculated to measure the nutritional status of mothers; this study showed that; mothers in Alemtidad were mainly overweight and obese (class I and class II), 45.6\% and 17.77\% respectively and only 35.6\% within normal range of BMI according to international WHO classification. As seen in Figure 1.

The nutritional status determinants in Table 2 shows that; about $37.8 \%$ of mothers do not take their meals regularly, while $5.6 \%$ have food taboos, and about $94.4 \%$ do not take three meals a day, many of them take more sugar $30 \%$, more salt $40 \%$, more oil $23.3 \%$ and more carbohydrates $54.4 \%$. The table also shows that about $71.1 \%$ of mothers take two meals per day and $23.3 \%$ take one meal per day, and only $5.6 \%$ take three meals per day, and it also shows that; $31.1 \%$ of mothers have chronic diseases. The relationship between body mass index and its determinants showed in Figure 2.

No significant relations between nutritional status of mothers and its supposed determinants at $95 \%$ level of confidence.

\section{Discussion}

Recently, different anthropometric measurements have been used in health system and in different studies abroad to assess the nutritional status, including WHO’ BMI classification.

Table 1. Characteristics of surveyed mothers in Alemtidad area, Khartoum $(\mathrm{n}=180)$.

\begin{tabular}{|c|c|}
\hline Variable & n (\%) \\
\hline \multicolumn{2}{|l|}{ Employment Status } \\
\hline Employed & $80(44.4 \%)$ \\
\hline Unemployed & $100(55.6 \%)$ \\
\hline \multicolumn{2}{|l|}{ Level of Education } \\
\hline Illiterate & $8(4.4 \%)$ \\
\hline Primary & $36(21.1 \%)$ \\
\hline Secondary & 70 (38.9\%) \\
\hline University & 64 (35.6\%) \\
\hline \multicolumn{2}{|l|}{ Economic Status } \\
\hline Good & 52 (28.9\%) \\
\hline Fair & $102(57.8 \%)$ \\
\hline Poor & 24 (13.3\%) \\
\hline \multicolumn{2}{|l|}{ Food Type } \\
\hline Home Made & $168(93.3 \%)$ \\
\hline Out Home Made & $12(6.7 \%)$ \\
\hline \multicolumn{2}{|c|}{ Food Access Difficulty } \\
\hline Yes & $46(25.6 \%)$ \\
\hline No & $134(74.4 \%)$ \\
\hline \multicolumn{2}{|c|}{ Body Mass Index (BMI) } \\
\hline Mean & $26.66 \mathrm{Kg} / \mathrm{m}^{2}$ \\
\hline Std. Deviation & 4.145 \\
\hline Minimum & 16.95 \\
\hline Maximum & 38.41 \\
\hline \multicolumn{2}{|l|}{ Age } \\
\hline Mean & 39.85 years \\
\hline Std. Deviation & 5.31 \\
\hline Minimum & 18.00 \\
\hline Maximum & 75.00 \\
\hline
\end{tabular}


Table 2. Nutritional status determinants of women in Alemtidad area $(\mathrm{n}=180)$.

\begin{tabular}{|c|c|c|c|c|}
\hline No. & \multicolumn{2}{|c|}{ Item Total $(\mathrm{n}=180)$} & Freq. & $\%$ \\
\hline \multirow{2}{*}{1.} & \multirow{2}{*}{ Regularity of meals } & Yes & 112 & $62.2 \%$ \\
\hline & & No & 68 & $37.8 \%$ \\
\hline \multirow{2}{*}{2.} & \multirow{2}{*}{ Food taboos (eating, cooking) } & Yes & 10 & $5.6 \%$ \\
\hline & & No & 170 & $94.4 \%$ \\
\hline \multirow{3}{*}{3.} & \multirow{3}{*}{ No. of meals } & One & 42 & $23.3 \%$ \\
\hline & & Two & 128 & $71.1 \%$ \\
\hline & & Three & 10 & $5.6 \%$ \\
\hline \multirow{4}{*}{4.} & \multirow{4}{*}{ Meals Contents } & More sugar & 54 & $30 \%$ \\
\hline & & More salt & 72 & $40 \%$ \\
\hline & & More oil & 42 & $23.3 \%$ \\
\hline & & More carbohydrate & 98 & $54.4 \%$ \\
\hline \multirow{2}{*}{5.} & \multirow{2}{*}{ Chronic diseases(diabetes, hypertension) } & Yes & 56 & $31.1 \%$ \\
\hline & & No & 124 & $68.9 \%$ \\
\hline
\end{tabular}

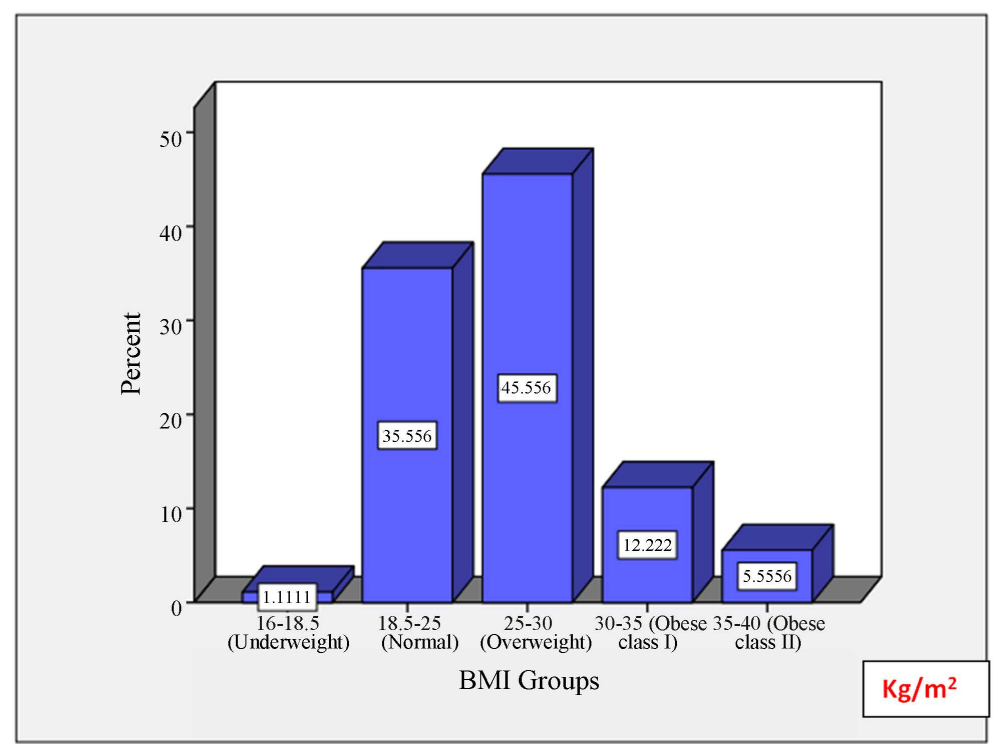

Figure 1. Maternal nutritional status measured by BMI $\left(\mathrm{Kg} / \mathrm{m}^{2}\right)$ in Alemtidad area, Khartoum, $(\mathrm{n}=180)$.

Nutritional status of mothers is one of the major problems facing the mothers in the world. Nutrition plays a major role in maternal and child health. Poor maternal nutritional status has been related to adverse birth outcomes; however, the association between nutritional status of mothers and birth outcome is complex and is influenced by many biologic and demographic factors, which vary widely in different populations. Assessing the nutrition status of mothers and understanding the relationship between maternal nutrition and other determinants are the main concerns of this study.

The Body Mass Index was calculated to measure the nutrition status of women; this study shows that, women in Alemtidad area are mainly overweight and obese, $45.5 \%$ and $18 \%$ respectively and only $35 \%$ within normal range of BMI. These findings differ from national reported by SuRF, 2002 which indicated that $27 \%$ of women are overweight and $4 \%$ are obese with mean BMI $22.5 \mathrm{Kg} / \mathrm{m}^{2}$ [9]. Our study concludes that mothers in Alemtidad 


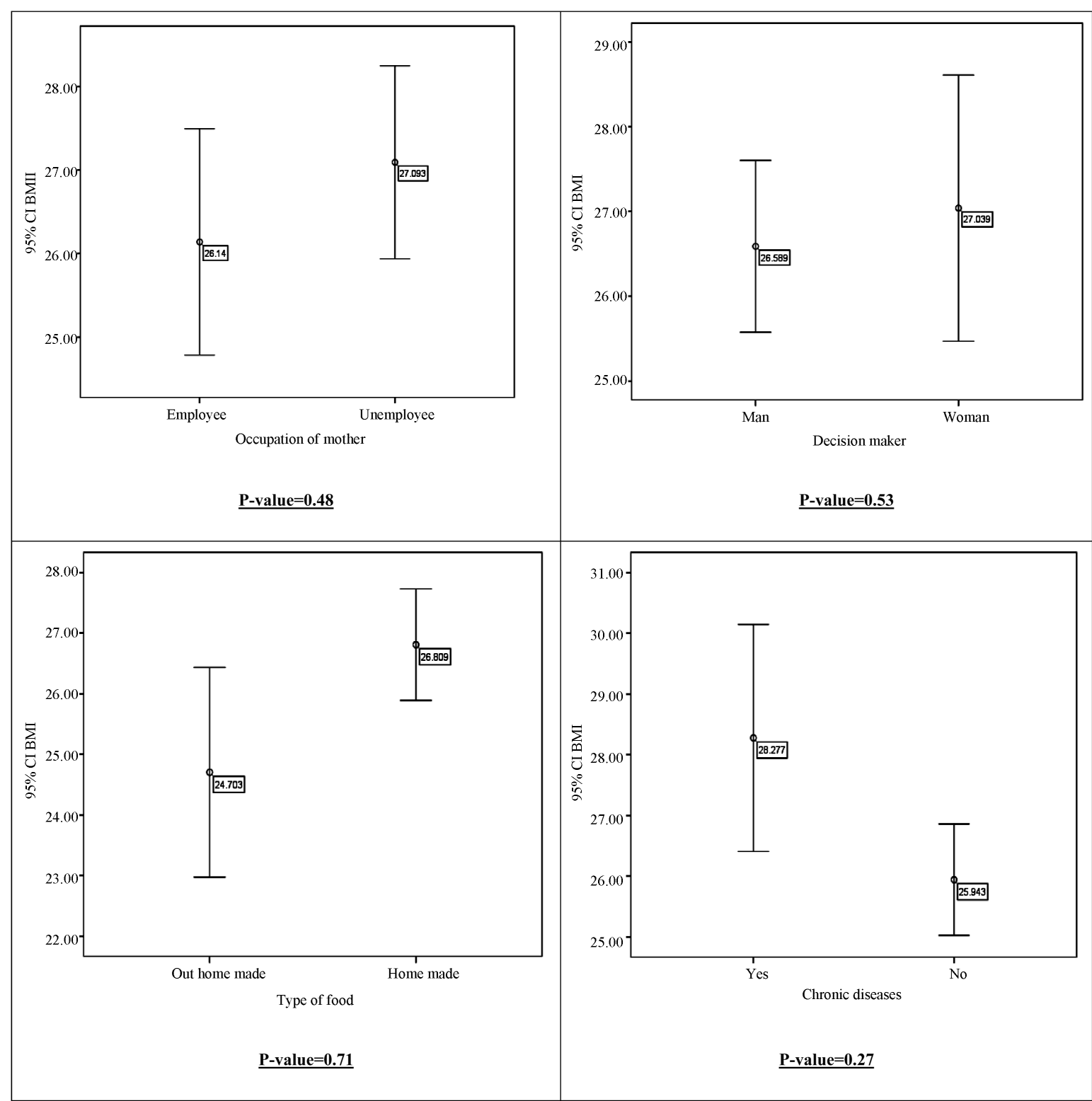

Figure 2. Relationship between Body Mass Index of mothers and its determinants in Alemtidad area, Khartoum. No significant relations between nutritional status of mothers and its supposed determinants at $95 \%$ level of confidence.

are either overweight or obese ( $45.6 \%$ - $17.7 \%$ respectively).

The determinants of nutritional status for mothers are many as mentioned in literature. In this study a relationship between mothers' nutrition status and other factors (education of mothers, occupation of mothers, food types, and decision maker in home regarding nutrition) was investigated. The results reported show that the relationships between nutrition status of mothers and determinants were not significant. The findings are opposite to findings of Ethiopian study which showed that, household economic status is one of the most important determinants of nutritional status in Ethiopian mothers, this finding is not consistent with other studies and the UNICEF conceptual framework [1] [9].

All investigated factors showed no significant relationship with mothers' nutritional status such as economic status, education level, and employment status. These findings differ from national reported by WHO, 2012 which indicated that $27 \%$ of mothers were overweight and $4 \%$ were obese with mean BMI $22.5 \mathrm{Kg} / \mathrm{m}^{2}$ [10] [11]. This study is unique in matter that it was conducted to assess maternal nutritional status in developing country 
which lack information about this point. Although this study was conducted at Alemtidad area in Khartoum State, the results can be used to inform health authorities to target similar communities in the country to improve nutritional status of mothers.

\section{Acknowledgements}

The authors would like to acknowledge surveyed mothers for their contributions and participation in this study.

\section{Authors' Contributions}

All authors are participated equally in this part of the study.

\section{References}

[1] Ene-Obong, H.N., Enugu, G.I. and Uwaegbute, A.C. (2001) Determinants of Health and Nutritional Status of Rural Nigerian Mothers. Centre for Health and Population Research, Bangladesh.

[2] McGuire, J.S. and Popkin, B.M. (2010) The Zero-Sum Game: A Framework for Examining Women and Nutrition. Food and Nutrition Bulletin, 10, 27-32.

[3] Lammi-Keefe, C.J., Couch, S.C. and Philpson, E. (2008) Handbook of Nutrition and Pregnancy. Humana Press, New York.

[4] Janaina, D., Vasconcelos, G.M., Torloni, M.R., Fisberg, M. and Sampaio, I.D.P.C. (2012) Nutrition Status. Maternal and Child Nutrition.

[5] Chandra, D.C. (2008) Societal Factors and Pregnancy Outcome. Nepal Journal of Obstetrics and Gynaecology, 3, 156162.

[6] Aydemir, F., Cavdar, A.O., Soylemez, F. and Cengiz, B.P. (2003) Plasma Zinc Levels during Pregnancy and Its Relationship to Maternal and Neonatal Characteristics: A Longitudinal Study. Biological Trace Element Research, 91, 193-202. http://dx.doi.org/10.1385/BTER:91:3:193

[7] Tuntiseranee, P., Olsen, J., Chongsuvivatwong, V. and Limbutara, J. (1999) Socioeconomic and Work Related Determinants of Pregnancy Outcome in Southern Thailand. Journal of Epidemiology \& Community Health, 53, 624-629.

[8] Ugwuja, E.I., Akubugwo, E.I., Ibiam, U.A. and Obidoa, O. (2011) Maternal Sociodemographic Parameters: Impact on Trace Element Status and Pregnancy Outcomes in Nigerian Mothers. Journal of Health, Population and Nutrition, 29, 156-162.

[9] Girma, W. and Genebo, T. (2012) UNICEF Ethiopia: Nutrition Status of Mothers. http://dhsprogram.com/pubs/pdf/FA39/02-nutrition.pdf

[10] WHO (2011) Nutrition Country Profile Republic of Sudan. http://www.fao.org/ag/agn/nutrition/assessment_en.stm

[11] Administration Committee on Coordination-Sub-Committee on Nutrition (ACC/SCN) (1990) Women and Nutrition. Symposium Report, Nutrition Policy Discussion, 6. 
Scientific Research Publishing (SCIRP) is one of the largest Open Access journal publishers. It is currently publishing more than 200 open access, online, peer-reviewed journals covering a wide range of academic disciplines. SCIRP serves the worldwide academic communities and contributes to the progress and application of science with its publication.

Other selected journals from SCIRP are listed as below. Submit your manuscript to us via either submit@scirp.org or Online Submission Portal.
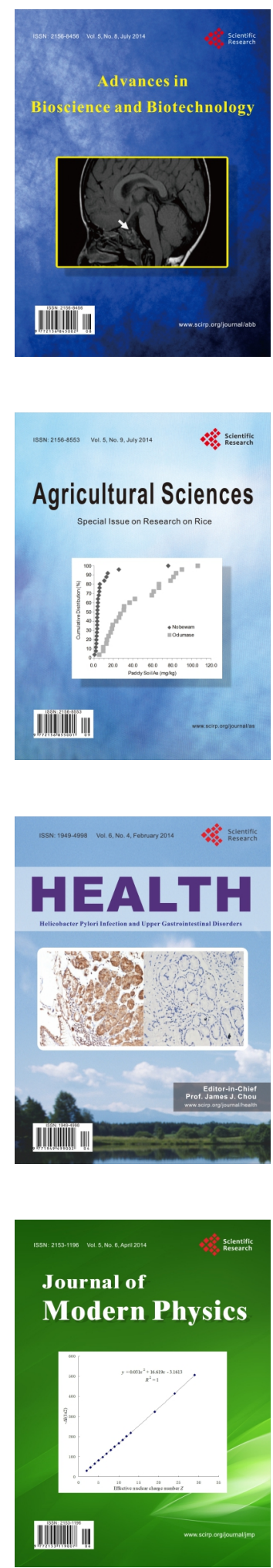
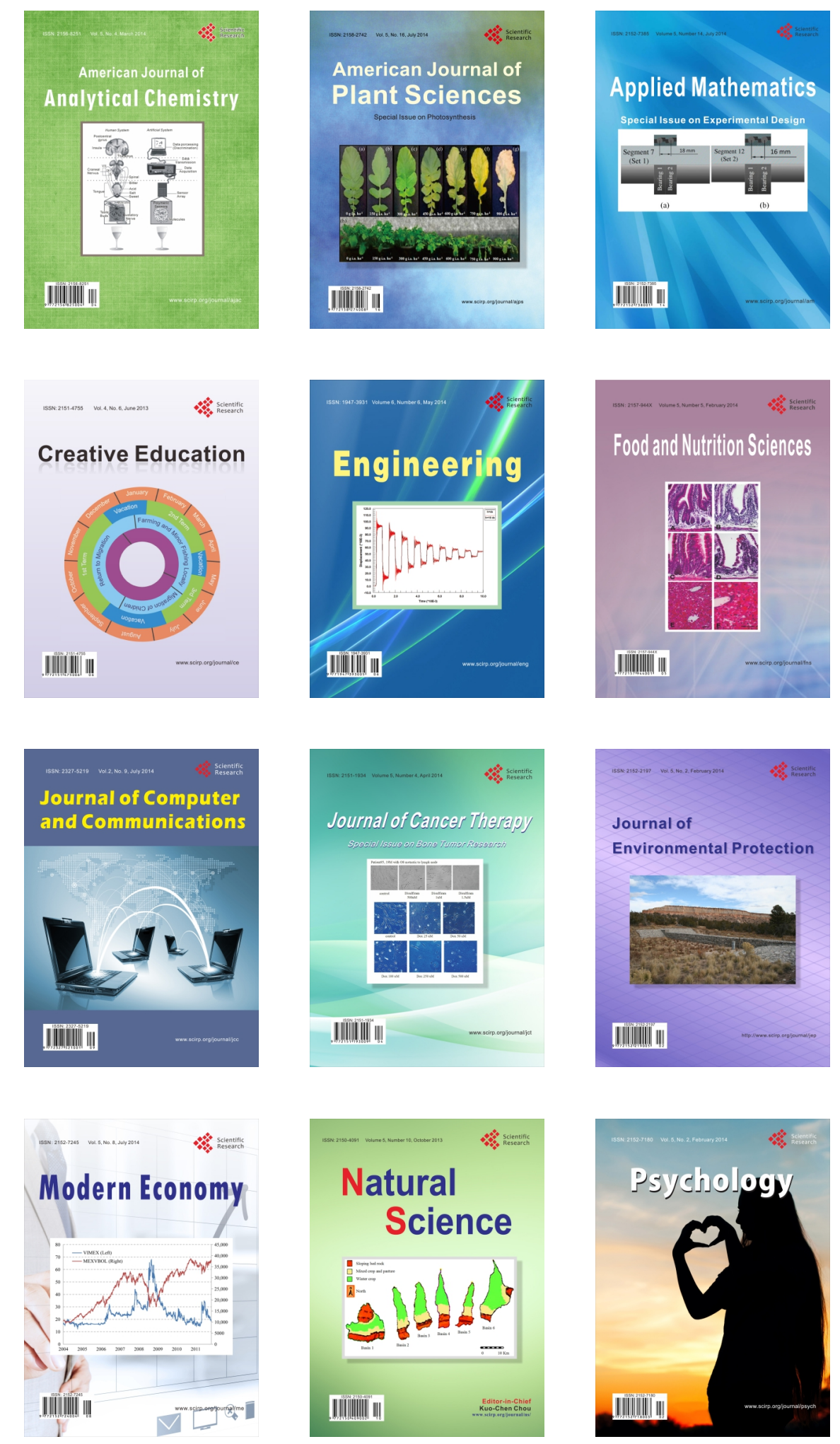